\title{
The Sorrow and the Pithy: Six Short Statements on Heidegger and Technology
}

Kent de Spain

$\mathrm{O}$ $\mathrm{n}$ the 20th of February, 1909, in a brazenly public act of technophilia, F.T. Marinetti carved his initials on the front page of Le Figaro and fired a starting pistol for the headlong human race into the future. Forty-five years, two world wars, and 100 million casualties later, someone finally stopped to ask for directions. In his 1954 essay, "The Question Concerning Technology" (TQCT), Martin Heidegger digs both heels into the ground and, in his own inimitable way, undertakes a meandering philosophical pilgrimage to the "essence" of technology. That essence, as he develops it, has ominous implications for the future of mankind, and yet Heidegger also offers an avenue of hope. In the years since Heidegger's analysis, many dance artists — myself included — have been stretched between two poles: wanting to reach out a hand to embrace a technological future, while knowing the other must still cling to our embodied past. Heidegger's words - the reification of his struggles to understand and articulate the role of technology in his own experience and, through his experience, in human life-can shed some light on our choreographic and aesthetic concerns.

\section{Unfree}

Despite a clear attempt not to jump to conclusions in his careful dissection, Heidegger drops a bombshell early on in TQCT:" .. whether we passionately affirm or deny [technology] ... we are delivered over to it in the worst possible way when we regard it as something neutral."1 A tool is not just a means to an end, a telephone not teleological. Technology is now positioned between humans and being, between the dancer and her dancing. We all now understand the fact that live, three-dimensional movement is inevitably and irrevocably changed when "captured" and "processed" by imaging technologies. What is less clear, but more disturbing, is the thought that we, too-as dancers and humans — are changed in the technological encounter, migrating unnoticed from subject to object. It is no coincidence that Laura Mulvey developed her take on "gaze" theory through the cinematic lens. But with her eye fixed on gender dynamics she may have stopped short of the fuller implications. How we see and understand each other and ourselves is now framed and altered by the objectifying gaze of technology. We have become processed for our own consumption. I do not think that Heidegger would disagree with my adaptation of Lacan: modern man is a symptom of technology.

\section{Gestell}

For Heidegger, the essence of technology is gestell, a process of "enframing," a "challenging-forth" to reveal. Although this idea has some dire implications (see \#5 below), in its simplest form 
enframing is certainly an accurate description of screendance, both in theory and in praxis. But it is easy to be so mesmerized by the motion and meaning in front of us that we forget that the act of enframing is also an act of excluding, the revealing always also a concealing. ${ }^{2}$ Admittedly, making art is making choices. Often, the clearer the choices, the more successful the art. As Anne Bogart points out, "To be decisive is violent ... it destroys every other possible choice, every other option." $\mathrm{A}$ frame is an aperture into a world. It discloses a unique logos, a telos. But death rides piggyback on every act of creation, so we should glance, on occasion, beyond the frame and into the shadows to see what has been cast aside.

\section{Just us volk}

Despite his importance as a philosopher and thinker, it is now impossible, politically and historically, to separate Heidegger from his association with National Socialism in Germany, and his statements and actions in support of Hitler and the Nazi party. The idea of a powerful central government integrating technology, education, and politics in support of the German "people" (volk) must have sounded like nirvana after the chaos of the late Weimar Republic. But the frightening reality of the Nazi use of technology-and the narrowness and violence of their concept of "people" — clearly influenced Heidegger's later concerns in TQCT. Even in a field as innocuous as dance, the politics of technology persists. Who has access to technology? What "people" does it document and serve? Social media and the accessibility of low-end technologies have had a democratizing influence, but high-end equipment (mo-cap, infrared sensing systems, etc.), and the expertise necessary to program and use it, is still beyond the reach of most dancers, particularly those on the cultural margins. What are we missing without them?

\section{Gerund-ing}

Heidegger was in love with the gerund. In wresting control of language in order to articulate his understanding of being, Heidegger queered the surety of verbs, their tendency to be fixed in time and space. As pointed out by Fraleigh, "It seems he wanted to dance being with words. A thing (anything and everything —entity and phenomenon) is not merely a presence-it 'presences' as a 'presencing."'4 But Heidegger's gerunds also compel his ideas into forced labor camps, forever in constant action, an unending state of becoming. In gestell —enframing - Heidegger sees the essence of technology as something not technological, something moving beyond our control; omnipresencing. In his final interview in Der Spiegel he says: "Technology is in its essence something that human beings cannot master of their own accord." ${ }^{5}$ Without our own constant revealing, we could find ourselves in Richard Brautigan's poetic future, when we are "all watched over by machines of loving grace."

\section{Dasein of da times}

It is easy to get so lost in Heidegger's rhetoric that you can miss the practical consequences of his analysis, and this is especially true in TQCT. For Heidegger, the effect of gestell, that challenging-forth toward revealing, is that everything manifests as "standing-reserve." Nature is harnessed through technology to be kept at the ready. That doesn't sound so bad, does it? 
If we need electricity, it is there when we throw the switch. If we need to travel, an airplane is waiting at the terminal gate. But standing-reserve is more than just keeping "enough" of something handy. It is a fundamental reprogramming of being (dasein). In its "setting-upon that challenges forth the energies of nature," technology "unlocks and exposes" nature so that it can be "stockpiled."7 Screendance makes an interesting case study here. Dance was once a scarce resource. It was embodied, and dependent on place and context. Any particular manifestation of dance could happen only once. But Heidegger's construction of gestell would see imaging technologies such as film or video as setting-upon dance for the purpose of extracting some dance essence, challenging-forth dance by pulling it out of being to be stockpiled as standing-reserve. This not only allows spatial and temporal displacement of dance, but also encourages de-contextualization and re-contextualization based on nowpresent personal and/or cultural desires. It also allows the efficient and repeated use of something that was previously defined by its ephemerality. In many ways this is a gift, but I see it as one with Maussian implications. We may all understand that screendance and dance are fundamentally different entities, but the moment we accept the former in any way as a substitute for the latter (as opposed to a complement or comment) we are obligated to repay the giver. Do we know the price we are paying?

\section{The Piety of Thought}

Despite the slowly gathering gloom of Heidegger's essay, he does not, in the end, consign mankind to standing-reserve in service of technology. Instead, he offers a ray of hope through a very human process: poiesis. Heidegger sees in poiesis humanity's role in his metaphysics: a pursuit of truth, a fundamental questioning that uncovers the roots of being by helping being find form. As expounded by Di Pippo in his analysis of Heidegger's use of the term, "poiesis is a response to an overpowering experience of absence and instability," and art, emerging from the poietic, "opens up a world of stable intelligibility and so orients [being]."8 Okay, but how does that help?

Perhaps Heidegger anticipated the razor's edge upon which we now sit as screendance artists, balanced precariously between embodiment and technology, because his antidote to the dangers of technology is to deeply and relentlessly question the essence of technology, not just in abstraction, but through the process of creation. We need to make work. And as we delve into the materials of that working process-humans in motion, light and shadow, focus and framing - we need to attend to what we find out about ourselves. Will looking through a viewfinder make us see the world with technological eyes, capturing the essence of dance to fulfill digital desires? Will we want to embody the technologies, bringing them into our intimate sensory and kinesthetic spaces and, by so doing, somehow humanize them? If Heidegger could shape his human thought toward exposing the essence of technology, can we not somehow cleave a path with and through technology to reveal more about the essence of humanity?

There are still dangers, but they are of our own making. If we abdicate responsibility, if we say technology is a "tool," then we pretend that it exists apart from us, and Luddites and technophiles can sit back and argue its merits and morals. There is a reason we feel a tension between ourselves and technology: we are tethered, so much so that we can no longer find the border between us. If we want to move, we must move forward together. 
In the end, "The Question Concerning Technology" is less a philosophical treatise than it is an ethical call to arms. By example and through his ideas Heidegger exhorts us to engage, and through engagement question, and through questioning come to awareness, and through awareness act, and through action mold our being-in-the-world. "The Question Concerning Technology" is the question concerning humanity: can we maintain our values throughout our complex negotiations with the world around us? In the face of everything he understands about the essence of technology, Heidegger still votes yes.

\section{References}

Augstein, Rudolf and Georg Wolff. Interview with Martin Heidegger, September 23, 1966. Reprinted as "Nur noch ein Gott kann uns retten." Der Spiegel. May 31, 1976.193-219. Digitized at http://web.ics.purdue.edu/other1/ Heidegger\%20Der\%20Spiegel.pdf. 1-18.

Bogart, Anne. A Director Prepares: Seven Essays on Art and Theatre. London: Routledge, 2001.

Brautigan, Richard. The Pill Versus the Springhill Mine Disaster. New York: Dell Publishing, 1968.

Di Pippo, Alexander Ferrari. "The Concept of Poiesis in Heidegger's An Introduction to Metaphysics."Edited by David Shikiar. Thinking Fundamentals: IWM (Institut für die Wissenschaften vom Menschen) Junior Visiting Fellows Conferences 9, no.3 (2000): 1-33.

Fraleigh, Sondra Horton. Dance and the Lived Body: A Descriptive Aesthetics. Pittsburgh, PA: University of Pittsburgh Press, 1987.

Heidegger, Martin. "The Question Concerning Technology." The Question Concerning Technology and Other Essays. Translated by W. Lovitt. New York: Harper Torchbooks, 1977. 3-35.

\section{Notes}

1. Heidegger, "The Question," 4.

2. Choreography is also an enframing practice - a technology all its own-but, to my mind, it more easily exceeds its frame, spilling over into space and experience. Screendance tends to be more tightly controlled; it is both flattened and narrow and, therefore, more focused.

3. Bogart, A Director Prepares, 45.

4. Fraleigh, Dance and the Lived Body, 164.

5. Augstein and Wolff, Der Spiegel interview, 9.

6. The Pill Versus the Springhill Mine Disaster, 1.

7. Heidegger, "The Question," 15.

8. Di Pippo, The Concept of Poiesis, 32. 